\title{
POTENTIAL IMPLICATIONS OF COVID-19 ON WORK AND EMPLOYMENT IN GHANA
}

\author{
Barbara Naa Amanuah Tetteh, University of Professional Studies, Accra, Ghana \\ Jibreel Ustarz Abubakar, University of Professional Studies, Accra, Ghana
}

\section{dx.doi.org/10.18374/RBR-20-1.5}

\begin{abstract}
COVID-19 is impacting the world of work and employment globally and nationally. Its impact has permeated the very fabric of life in multiple ways such as the following: the employee employer relationships, business continuity issues, health and safety (Preparing for a pandemic, responding to a pandemic, communicating during a pandemic), finance and cost implications, customer service issues. There must be an adjustment, and changes to the nature of work; and this also requires a rethinking of the social contract ("World Bank, 2020"). Additionally, there must be newer ways to protect people and invest in them irrespective of their employment standing. ("World Bank, 2020").
\end{abstract}

Keywords: Covid-19, Work and employment, Employee Employer Relationships, Human Resource Management 